\title{
複数館種を対象とした高校生の図書館利用行動に関する実態調査
}

\section{Factual research of library using behavior in high school students}

\author{
小野永貴 ${ }^{1,2 *}$, 德光亜矢子 ${ }^{1}$, 下山佳那子 ${ }^{2}$, 佐藤翔 ${ }^{3}$ \\ Haruki ONO ${ }^{1,2 *}$, Ayano TOKUMITSU ${ }^{1}$, Kanako SHIMOYAMA $^{2}$, Sho SATO $^{3}$
}

1 お茶の水女子大学附属高等学校

Ochanomizu University Senior High School

干112-8610 東京都文京区大塚2-1-1

E-mail: ono.haruki@ocha.ac.jp

2 筑波大学大学院 図書館情報メディア研究科

Graduate School of Library, Information and Media Studies, University of Tsukuba

干 305-8550 茨城県つくば市春日 1-2

E-mail: milkya@slis.tsukuba.ac.jp

3 同志社大学 社会学部 教育文化学科

Faculty of Social Studies, Doshisha University

干602-8580 京都市上京区新町通今出川上ル

*連絡先著者 Corresponding Author

近年、学校図書館の連携に関する実践が盛んである。特に高等学校の場合、公共図書館が学校 を支援したり、大学図書館が高校生向けに開放する等の事例も増え、高校生が複数館種を相互に 活用できる機会も多い。しかし、実際に生徒が各館種をどう使い分けているか、実態は明らかでない。 そこで本研究では、高校生 28 人を対象としたフォーカス・グループ・インタビュー調査を実施した。全 発話内容の書きおこしと分析を行い、高校生が複数の館種を使い分ける際の基準となりうる要素を 抽出した。

Recently, library cooperation is being tried by many school libraries. The cooperation between public library, university library and school library is possible for high school library. However, it is not clear how high school students are seeking information from these libraries. We conducted focus group interviews of 28 high school students, and analyzed sentences of dialogs. Finally, we considered about what is merit or demerit for high school students in each library type.

キーワード: 学校図書館, 高校生, 情報探索行動, フォーカス・グループ・インタビュー

school library, high school students, information seeking behavior, focus group interview 


\section{1 はじめに}

近年、学校図書館が近接する他の図書館と 連携する試みが、多数行われている。特に高 等学校においては、スーパーサイエンスハイ スクール事業の実施等により、特定分野に特 化して高度な教育実践が行われることも多 くなったが、予算規模や人的配置上、これら の高度教育に学校図書館だけで全て対応し きるのは困難である。そのような際に他の館 種の図書館との連携体制があれば、生徒の学 習機会を大きく拡げ、個々の関心に応じて探 求をより深められる可能性もある。

連携対象の館種としては、小・中学校図書 館の場合、公共図書館との連携が数多く実践 されている。（資料の相互貸借や物流システ ムの構築、ブックトーク・訪問授業やスタッ フ派遣など。）また、高等学校図書館の場合、 前述のような教科教育の高度化に伴い、専門 的資料や人的サポートを求めて、公共図書館 のみならず、近接する大学図書館との連携も 注目され始めている。実際に、高校生が近接 する大学図書館を利用できる体制をとる学 校もあり、そのような学校に所属する高校生 は、学校図書館・大学図書館・公共図書館の 3館種にまたがって、目的に応じて相互に使 い分けて学習をすることができる。

このように、学校図書館が複数の館種と連 携を行うにあたり、具体的にどのような連携 を行うのが効果的であるのか、様々な施策が 工夫されている。しかしその多くは、学校司 書・司書教諭をどのようにサポートするかと いった司書の人的支援の観点や、資料の団体 貸出・授業での一括利用の円滑化といった資 料物流の観点など、図書館運営側の視点での 工夫が多かった。確かに、これまでの他館連 携の中心であった小・中学校の場合、生徒が 能動的に複数の図書館を使い分けて資料を
選別しながら学習を行うことは難しく、授業 や到達目標に応じて教員側が他館活用の時 間を設定し、明示的に利用を促すことが主な 活用形態であったと考えられる。しかし、高 等学校の場合は、生徒自身が館種毎の蔵書や サービスの違いをある程度認識し、目的に応 じて使い分けている生徒も少なからずいる のではないだろうか。このような、生徒が複 数の図書館を用いて情報を探索する際の「情 報探索行動」の観点から生徒の利用実態を調 査・把握し、その上で他館連携の施策・工夫 を検討した学校図書館の実践は、過去に例が ない。

そこで本研究は、複数の図書館を使い分け て学習を行いうる高校生が、どのように図書 館を使い分けて情報探索を行っているか、実 態を明らかにすることを目的とする。特に、 過去の先行事例が少ない学校図書館と大学 図書館・公共図書館の使い分けに着目し、調 查を行う。これらの調查を通し、学校図書館 が他館と連携を行う際に、有効な施策を検討 できるような、基礎的な要素を抽出すること を目指す。

\section{2 先行事例}

これまで、学校図書館と公共図書館が連携 し、児童・生徒が相互の図書館を活用した教 育実践は数多く行われてきたが、学校図書館 と大学図書館の相互利用・連携の試みは数少 ないと考えられる。そこで、本研究では大学 図書館と学校図書館の相互利用・連携の事例 について、先行事例の調查を行った。

三重県津市では、平成16年度から3年間、 文部科学省より委嘱を受けて「学校図書館資 源共有ネットワーク推進事業」を実施した。 この事業は、津市教育委員会の要請のもと、 三重大学附属図書館が社会・地域連携の一環 
として参画し、学校・公共・大学図書館の3 者が連携して学校図書館向上を図った試み である。具体的な実施内容は、中井らにより 次のように報告されている $[1]$ 。「大学図書 館職員の専門性を生かした情報リテラシー 支援を中心とした活動を行ってきた。（中 略）学校図書館の状況においては、運営に不 可欠な専門知識やスキルが不足しがちであ ること、またそれに対し専門職としての大学 図書館職員の参加が予想した以上に有効で あるということが把握された。」

このように、この事例は大学図書館による 学校図書館の運用面のサポートが中心であ り、委員会等での専門的アドバイスや、学校 図書館関係者に対する講習会開催が、主な実 施内容であったことが述べられている。また、 上記論文中では大学図書館側の職員が学校 図書館の活動（保護者等ボランティアによる 巡回指導，読夕聞かせ等）を見学し、意見交 換を行いつつも、「実際に大学図書館として 支援できることはほとんどなかった」とも述 ベられており、度重なる議論を行いつつ「大 学図書館がすべきことを模索した」と、連携 施策検討の難しさが指摘されている。

その他の事例としては、2008年の中戸川の 論文 [2]において、相模女子大学附属学校で の学校図書館・大学図書館の連携施策の検討 過程が報告されている。この論文中では、学 校図書館・大学図書館の連携事例を、次の5 類型に分類している。

（1）児童図書室の設置 (大学図書館内一生 徒・览童が利用できるスペースの新 設）

（2）人的支援（学校図書館の司書・司書教 諭を対象としたレクチャー等)

（3）資料貸出 (大学図書館の所蔵資料を一 時的に学校図書館へ一括貸出して補
充)

（4）大学図書館と学校図書館の連携 (大学 図書館を高校生が利用できる，もしく は大学生が学校図書館を利用でき る。）

（5）授業利用（授業のクラス単位で大学図 書館を訪問し利用する)

中戸川は論文の考察において、まず考えら れるのは(1)としつつ、将来的には (4)の本格 的連携へ移行したいと述べており、高校生が 大学図書館も含めて複数館種を使い分ける 連携施策は、将来的課題と位置づけられてい る。また、この研究ではインタビュー調査も 実施されており、その結果、学校図書館と大 学図書館の連携において大事なこととして、

「大学図書館員が学校図書館を知ろうとし、 大学図書館からアクションを起こすこと」

「上司をうまく説得すること」「学校図書館 を利用する教員の意識と、学校図書館司書の アピール」の三点が挙げられている。

いずれの先行事例においても、連携先の図 書館側の立場からの視点、もしくは学校図書 館を運営する立場からの視点で検討されて おり、主たる利用者となる学校の生徒の視点 では、実態の調査がなされていない。

\section{3 調査方法}

\section{1 対象}

複数の館種を利用可能な高校生が、どのよ うに情報探索を行っているか明らかにする ために、本研究の目的を満たすA高等学校の 生徒を対象としたインタビュー調査を実施 した。調査対象のA高等学校は、総合大学の 付属学校であり、大学キャンパスと近接した 位置に高等学校の校舎がある。大学図書館も 高等学校校舎から徒歩圈内に位置し、付属高 
等学校の生徒も大学図書館の施設・蔵書を利 用可能なよう、高大連携が長期にわたって実 施されている。

\section{2 手法}

集団面接法の一種である「フォーカス・グ ループ・インタビュー」を用いた。フォーカ ス・グループ・インタビューとは、特定の属 性に適合する複数人の被験者を集め、司会が 話題を提示しながら被験者相互に自然な会 話を行わせる中で、本意の発話を抽出する質 的調査手法である。本手法は、グループダイ ナミクスを利用寸ることで、調査対象の深層 の意見を自然な発話から収集することがで きる。また、他の調査手法に比べて、準備か ら実施、集計までのプロセスが早いことも利 点とされている。

今回の場合、質問紙調査により個々の生徒 の日常行動を聞き取る手法も考えられたが、 高校生の図書館利用行動の種別や類型を最 初から想定することは困難であったため、予 め質問項目を指定した画一的な質問紙調査 は適さないと判断した。また、面接に慣れて いない高校生を被験者とするため、質問者と 一対一で聞き取りを行う個別面接法は、必要 以上に被験者に緊張感を与えてしまうと予 測され、潜在的な本意を引き出しにくくなる ことを避けるために、集団面接法を採用する こととした。

\section{3 被験者の属性}

インタビューは5回に分けて実施し、それ ぞれ異なる属性の生徒を被験者として集め、 近い属性の生徒同士で議論が促進されるよ う設定した。具体的に、各回における被験者 の属性は表1の通りである。

なお、A高等学校は1学年あたり定員120名
の小規模校であり、被験者の合計人数 28 名は、 全校生徒の約 $7.8 \%$ のンプルに相当する。

表1 インタビュー各回の被験者属性

\begin{tabular}{|c|l|}
\hline 回 & \multicolumn{1}{|c|}{ 被験者の属性・人数 } \\
\hline 1 & 一般生徒 $(1$ 年生) 7 名 \\
\hline 2 & 図書委員生徒 $(2$ 年生) 6 名 \\
\hline 3 & 図書委員生徒 $(1$ 年生) 5 名 \\
\hline 4 & 一般生徒 $(1$ 年生) 7 名 \\
\hline 5 & 図書館常連利用生徒 $(2 \cdot 3$ 年生) 3 名 \\
\hline
\end{tabular}

\section{4 インタビュー形態}

インタビューは、A高等学校図書室内の区 切られた小部屋で実施し、1回あたり 45〜90 分の時間を要した。被験者に謝金の支払いは 行っていないが、緊張感の緩和のため茶菓子 を提供した。話題制御を行う司会は、本研究 代表者の小野が務めた。また、全てのインタ ビュー内容について、ボイスレコーダーによ る発話音声の録音、ビデオカメラによる会場 映像の録画を行いつつ、研究協力者によって 話題概要の速記を行った。

\section{5 聞き取り内容}

フォーカス・グループ・インタビューでは 被験者同士の自然な会話が重視されるため、 司会による積極的な議論への介入は行って いない。原則的に、会話のきっかけとなる話 題の提供や問いかけ、および会話内容の要約 や話題のまとめを行い、会話内容が調査目的 から逸脱した場合のみ、議論への介入を行っ た。

具体的に、会話のきっかけとして提示した 話題は、主に以下の通りである。

・自己紹介および、学校の図書室をどのよ うに日常利用しているか

- 各教科の授業の課題等で図書館を利用 
することはあるか。また、その場合には どのように資料を探索するか。

- 近接する大学図書館や公共図書館は利 用するか。また、どのように利用してい るか。

- 資料を探索する際に、各図書館のOPAC やレファレンスサービス等の各種情報 サービスは利用しているか。

\section{4 調査結果}

\section{1 概要}

全インタビューの音声・映像記録 (合計約 375分間）に対して、発話内容の書きおこし 作業を行い、合計 6,480 文の発話記録を得た。 なお、各被験者の発話内容の他に、他者の発 話に対して同意・疑問を示す態度をとった者 や、多数の者が共感する雰囲気であった場合 など、特徵ある場面の状況も記録した。その うえで、次の手順で発話内容の傾向を分析し た。

1. 各発話に対して、話題としている館種の タグ付けを行った。（学校図書館・大学 図書館・公共図書館の3種を想定)

2. 各発話内容から、各館種の使い分けの基 準となりうる要素を抽出し、おおまかな コーディングを行った。

3.これらを実施しながら、当初想定してい なかったタグやコードが発話中で出現 した場合、適宜追加・修正を繰り返した。

4. 上記結果をもとに、各館種ごとに抽出さ れた要素を、「利用する理由・利用場面・ 期待感」（プラス面）および「利用しな い理由・利用を避ける場面」（マイナス 面）の2種類にわけ、全記録の中で繰り 返し頻出したものを傾向としてまとめ た。

\section{2 分析結果}

全体的な傾向として、学校図書館以外に利 用する図書館としては、公共図書館への支持 が大きいことが多数の発話で確認された。一 方、調查対象校は高校生も大学図書館を利用 できるよう連携を行っているにも関わらず、 生徒による大学㘠書館の利用に関する発話 は数少なく、限定的であった。具体的に、各 館種の使い分け基準として抽出された主な 要素を、プラス面・マイナス面にわけて傾向 をまとめたものが表2である。

\section{3 考察}

表2のような館種ごとの傾向があらわれた 理由を、筆者らは以下のように考察した。

まず、自宅居住地の近くの公共図書館は、 転居しない限り幼少期から長期にわたり利 用し、熟知し使い慣れ、安心感をもたれてい ると考えられる。一方、学校図書館は進学に 応じて次々変わるうえ、大学図書館に至って は利用経験がないため、コレクションやサー ビスに対する認識度が低く、利用が定着して いない傾向にある。特に、大学図書館につい ては蔵書構成やサービスの専門性を知らず に、学校図書館・公共図書館と同レベルの感 覚で資料を探索し、期待していた資料が無く 失望感を抱いた生徒が多かった。これは、館 種の特性認識の不足によるミスマッチが生 じていると解釈できるであろう。一方、空 間・施設的には大学図書館を有効活用してい る生徒も確認された。これまで図書館は「飲 食禁止で静かに読書する場」という固定観念 を抱いていた中で、ドリンクを飲みながら会 話をしつつグループ学習ができる大学図書 館内のスペースに、新たな利用価值を自主的 に見出したことが考えられる。 
表 2 書きおこし記録から抽出された館種ごとの使い分け要素

\begin{tabular}{|c|c|c|}
\hline & 利用する理由 - 利用場面 ・ 期待感 & 利用しない理由・利用を避ける場面 \\
\hline 学校図書館 & $\begin{array}{l}\text { 各教科の授業課題での図書利用／教 } \\
\text { 科学習に最適化された排架の工夫／ } \\
\text { 静寂な自習室／学校司書との会話／ } \\
\text { 他生徒とのコミュニケーション } \\
\text { ストセラー書でも早く入手可能 (リク } \\
\text { エスト・予約) }\end{array}$ & $\begin{array}{l}\text { 蔵書数の少なさ／図書持ち運びの重 } \\
\text { さ（電車学等による）／中学校時代 } \\
\text { とのギャッブ／資料探索失敗経験に } \\
\text { よる信頼の低さ／OPAC や排架順に } \\
\text { 対する誤解・認識不足／図書室のメン } \\
\text { テナンス不足 }\end{array}$ \\
\hline 大学図書館 & $\begin{array}{l}\text { 歴史書・社会学書等の専門的資料／新 } \\
\text { 聞バックナ゙ンの利用／映像資料 } \\
\text { などの多様なコレクション／会話・グ } \\
\text { ループ学習ができる学習環境 }\end{array}$ & $\begin{array}{l}\text { 専門書ばかりで難易度が高い印象／ } \\
\text { 期待した資料が無かった失望体験／ } \\
\text { 職員の案内やサービスについての不 } \\
\text { 信／サービスや OPAC についての誤 } \\
\text { 解／距離・時間的問題 }\end{array}$ \\
\hline 公共図書館 & $\begin{array}{l}\text { 蔵書量の豊富さ／幼少期からの長期 } \\
\text { 利用による安心感／OPAC や排架順 } \\
\text { の熟知／OPAC や予約・取り寄せシス } \\
\text { テムの充実／レファレンスサービス } \\
\text { での成功経験 }\end{array}$ & $\begin{array}{l}\text { ベストセラー書の入手困難性／蔵書 } \\
\text { 量・種類の過多 (多すぎてむしろ探し } \\
\text { づらい・使いづらい) }\end{array}$ \\
\hline
\end{tabular}

その他、レファレンスサービスや司書との 会話等の人的側面について注目すると、学校 図書館と公共図書館ではプラス面での発話 があったことに対し、大学図書館ではマイナ ス面の発話が確認された。これは、高校生の 大学図書館利用に対して、職員側にも理解が 不足している点があり、適切な支援が行えて いなかったことが推測される。

\section{5 結論}

本研究では、学校図書館・大学図書館・公 共図書館の3館種を利用可能な高校生に対し 調查を行ったが、単純に近接する図書館の利 用権を与えるだけでは、有効活用ができてい ない実態が明らかになった。今後は、館種ご との特性認識や、各館種の強みをいかした有 効活用を促す指導を行うことが、必要である と考えられる。また、円滑な活用を支援する ためには、生徒に対する指導だけでなく、館 種を超えた職員側での人的連携・情報共有も 必要であると考えられる。

本研究では使い分けの基準となりうる要
素を抽出したが、今後は各要素間の関連性や 階層関係など、構造化を行うことが課題とな る。また、これらの要素について、多様な環 境下の学校でも同様の傾向が現れるか、質問 紙調査等で広く検証することが望まれる。

\section{謝辞}

本研究の一部は、お茶の水女子大学附属高 等学校が文部科学省受託研究として実施し た「平成24年度 確かな学力の育成に係る実 践的調查研究」の一環として実施しました。 事業関係者の皆様には多数のご助言・ご支援 を頂き、心より御礼申し上げます。

\section{参考文献}

[1］中井えり子；伊東直人；佐藤義則：大学 図書館の学校図書館支援事業, 大学図 書館研究，78, p. 105-113， 2006.

[2] 中戸川陽子：大学図書館と学校図書館の 連携にむけて, 学校図書館学研究. 10 , p. 77-82, 2008. 